\title{
Public Opinion and Global Justice
}

Economic liberalization and globalization have exacerbated inequalities within and between nations, and brought poverty and human rights at the forefront of discussions of world politics (Doyle, 1997, pp. 422-36; Hurrell \& Woods, 1999). These issues are increasingly understood as questions of global justice, a concept introduced to stress the worldwide implications of moral problems. Reaching beyond the conventional domestic/international divide, debates about global justice consider redistribution and other questions of rights within as well as among nations, in the North as much as in the South (Shapiro \& Brilmayer, 1999, p. 2; Thérien, 1999; DeMartino, 2000).

These debates have been conducted primarily by political philosophers, concerned by the difficulty of arbitrating between the duties a person has toward her fellow citizens and toward all human beings (Jones, 1999). Cosmopolitans believe "that neither nationality nor state boundaries, as such, have moral standing with respect to questions of justice." Nationalists, on the contrary, consider "that our obligations to conationals are greater than our obligations to outsiders" (Satz, 1999, pp. 67-68). A range of viewpoints exists between these two positions, which themselves are not as far apart as they appear (see Beitz, 1999, p. 296). A cosmopolitan like Martha Nussbaum (1996, pp. 135-36), for instance, acknowledges "that it is right to give the local an additional measure of concern," even if we believe that all humans have "equal moral worth." On the nationalist side, David Miller (1999, p. 197) also recognizes the relevance of "principles of global justice," albeit in a more restrictive sense than cosmopolitans. These scholars seek to clarify the moral foundations of global justice. We propose to address the 
question in a different, more empirical way. To do so, we focus on public support for redistribution at home and abroad. The distribution issue is clearly the dominant theme in the literature, and public opinion data offer a good empirical basis to examine the actual politics of global justice.

The comparative literature on the welfare state and development assistance suggests that there is a link between a country's domestic and foreign commitments to redistribute (Pratt, 1989; Stokke, 1989a; Lumsdaine, 1993; Noël \& Thérien, 1995). Logically, this link should also be visible in public opinion. Indeed, in his work on the foreign aid regime, David Lumsdaine (1993, p. 138) establishes that individual attitudes toward domestic and international redistribution are coherent. Respondents who approve development assistance tend to be those who also favor social expenditures. Our comparison of aggregate public opinion across nations shows, however, that the association between public support for redistribution at home and abroad is strong and significant, but negative. In countries where domestic income redistribution is seen as an important priority, foreign aid is less popular; where this is less so, there is more concern for the fate of the poor in the South. These findings, which are in line with a host of studies on public opinion and the welfare state, do not invalidate Lumsdaine's general point about the coherence of public opinion. They lead, however, to an important qualification: domestic policy achievements strongly influence public attitudes about redistribution. In other words, taking into account a country's political context solves the apparent contradiction between Lumsdaine's results and ours. More generally, it clarifies how nationalist and cosmopolitan principles interact in public deliberations about global justice.

The article begins with a state of the art on the question of public opinion coherence, and then proposes a theoretical model that emphasizes the capacity of mass publics to take policy 
achievements into account. The data and results are then presented and analyzed, along with a brief discussion of the telling cases of Denmark and France. 


\section{State of the Art}

If public considerations about global justice are anchored in ideas and principles defined at the national level, a country's public opinion should be coherent across domestic and international redistribution issues. Sensible, this argument raises two questions, addressed more or less thoroughly in the literature on public opinion. First, there is the issue of coherence itself, the long debated possibility of a rational or reasonable public. Second, is the more specific hypothesis of coherent public support for redistribution at home and abroad, a hypothesis often taken for granted but rarely studied systematically.

Until recently, most students of public opinion presented respondents as minimally interested in politics and policy, poorly informed, and inconsistent across time and issues. They stressed "the frequency with which ordinary citizens failed to form even an opinion about many political issues" and noted how they usually "failed to put their ideas about politics together consistently" (Sniderman, 1993, p. 219). Coherence was not expected. Citizens appeared indifferent to public policy issues that provoked intense controversy among the elite (Page \& Shapiro, 1992, p. 6). They could not even be trusted to uphold the most fundamental democratic values, which they accepted in principle but failed to support when challenged (Sniderman, Fletcher, Russell, \& Tetlock, 1996, p. 11). The same was true with respect to foreign policy. Following the early assessments of Walter Lippman and Gabriel Almond, scholars portrayed public opinion as volatile, and lacking in structure and coherence. Depicted as inattentive and indifferent, citizens appeared to know little about world affairs and to change their opinion according to the circumstances, without respecting any logical constraints. In this context, public 
attitudes about domestic and international politics simply seemed unrelated (Holsti, 1992, pp. 442-43, 1996, p. 23-33).

In recent years, this understanding of public opinion has been challenged fundamentally, so much so that a new consensus has emerged. While they acknowledge that ordinary citizens have limited levels of knowledge about public affairs, analysts now portray the attitudes developed on this narrow basis as relatively stable, reasonable, and coherent (Sniderman, 1993, p. 220). Benjamin Page and Robert Shapiro (1992, p. 281), for instance, studied fifty years of American polls to find that, with foreign just as with domestic policy, public preferences "form coherent patterns that reflect underlying goals and values and beliefs, including strong desires for peace, international cooperation, and reliance on negotiations and agreements." When these preferences change, they do so because the public responds reasonably to events or to new information (Page \& Shapiro, 1992, p. 282). There is no agreement about the structure of public attitudes, but the new consensus is that it cannot be understood adequately with a few dimensions, such as the liberal-conservative or internationalist-isolationist dichotomies (Holsti, 1992, p. 448; see also Wittkopf, 1990). Ole Holsti (1992, p. 450) suggests that, "in the absence of much factual knowledge," citizens use "various heuristics" to "make some sense of an increasingly complex world." Paul Sniderman and his co-authors (1996, pp. 221 and 228) go further to argue that, beyond these genuine "judgmental shortcuts, or heuristics," citizens also tend "to strive for consistency, if not at the level of specific issues, then at any rate at the level of values." Responses that appear inconsistent may simply reflect the public's difficult reconciliation of a plurality of values (Sniderman, Fletcher, Russell, \& Tetlock, 1996, pp. 22728). 
In line with this new consensus, public attitudes are increasingly presented as consistent across the domestic/international divide. Bruce Russett (1993, pp. 130-31) goes so far as to suggest that the idea that "people's views on domestic politics are associated with their views on foreign policy is old news." ${ }^{1}$ There is some good evidence to that effect. Eugene Wittkopf (1990, p. 34), for instance, explains how the partisan preferences of Americans shape their understanding of foreign policy. In a more circumscribed study, Kevin A. Hill (1993, p. 208) finds that in the United States, "the overwhelming predictor of liberalism on South African sanctions is liberalism on racial attitudes." As with much of the literature on public opinion, however, the relevant findings tend to be limited to questions of high politics and to the American case (Holsti, 1996, pp. 204-05; Dalton, 2000, p. 921). Few studies have assessed directly public opinion on domestic and international redistribution, especially in a comparative perspective. $^{2}$

One notable exception is David Lumsdaine's ambitious cross-national exploration of the links between public support for redistribution at home and abroad. Attitudes about the welfare state and foreign aid provide a natural test case for the idea of domestic/international coherence in public opinion, because there is a well-established correspondence between a country's social policy institutions and its commitment to development assistance (Noël \& Thérien, 1995). Public opinion on these two questions appears rooted in similar values about justice (Stokke, 1989b, p. 284; Lumsdaine, 1993, pp. 119-21). In Moral Vision in International Politics, Lumsdaine (1993, p. 138) relies on different national poll results to conclude that individual support for foreign aid is rooted in consistent moral values and political views. Respondents favorable to "domestic programs of redistribution" appear more likely to approve development assistance (Lumsdaine, 1993, p. 43). These findings about individuals, argues Lumsdaine (1993, p. 168), also "parallel 
data on national differences." In each country, aid policy is anchored in "the same values which expressed themselves domestically in concern about issues of poverty" (Lumsdaine, 1993, pp. 143 and 179). ${ }^{3}$

Lumsdaine's work has offered new avenues to understand public opinion about global justice. His conclusions, however, leave some questions open. First, Lumsdaine assumes that if individuals are coherent, national publics will also be coherent, in the same manner. This may be true, but it is important to stress that aggregate public opinion measures collective, not individual, policy preferences. These preferences may well have properties "that are not shared by the individual opinions and responses that make them up" (Page \& Shapiro, 1992, p. 15). Second, Lumsdaine insists on the impact of moral values but does not pay much attention to the political context that structures public opinion and its expression. At the aggregate level, values about justice and equality may not differ all that much from one OECD country to the next (Rothstein, 1998, pp. 132-35). Equality, however, is a complex and multifaceted value that does not translate into public policy in a simple way (Papadakis \& Bean, 1993; Svallfors, 1993; Döring, 1994; Smillie, 1996, p. 45; Wood, 1996, p. 21). To understand the politics of equality, write Sniderman and his co-authors (1996, p. 247), it is necessary to pay attention to the issues at stake: "Political power is not won or lost in debates over equality, considered as a value and isolated from competing considerations, but in electoral arguments over public policy, arguments over what the government is specifically allowed or obliged to do." Third, Lumsdaine's analysis is based on 1983 data and it is far from certain that public support for domestic and foreign redistribution has remained steady and closely tied throughout years of austerity and retrenchment. In difficult times, public opinion favorable to foreign aid may not have been as solid and resilient as support for the welfare state (Esping-Andersen, 1999, pp. 147-48; Thérien \& Lloyd, 2000, p. 29). 
It is plausible that the public of donor countries holds coherent views about domestic and international redistribution. The evidence for such coherence, however, is dated and limited. Some results have been presented for specific countries, but they are not sufficient to offer general conclusions. As with other issues related to equality, the coherence of public opinion about global justice is likely to be more complex, less straightforward that is usually assumed.

\section{Theoretical Model}

Our theoretical argument builds on two basic ideas. First, as mentioned above, even if individual attitudes were coherent, collective preferences could still be distinct and constitute unexpected patterns. Second, public opinion is not simply an expression of pre-existing values. Mass publics take into account political debates and policy achievements, and respond to polls with concrete situations as well as with values in mind.

The first point, concerning aggregate preferences, is a simple, but often neglected, question of level of analysis. As a collective phenomenon, public opinion presents distinctive characteristics. It appears, for instance, more stable and structured than at the individual level (Page \& Shapiro, 1992, p. 15). The aggregate level of analysis also makes it easier to compare public opinion over time, and across space or issues. Finally, and most importantly, the aggregate approach is the best way to link public opinion to other aggregate-level variables, such as partisan power, institutions, or public policies. In his survey of the field, Paul Sniderman

(1993, p. 239) contends that the aggregate approach, which is still relatively recent, "throws a searching new light" and is likely to have a "powerful impact" on the study of public opinion and public policy. 
The second idea we wish to introduce is that public opinion must be understood in light of each country's political context and policy record. This idea is drawn from a series of comparative studies of public opinion and the welfare state that identified apparently paradoxical situations. In Culture Shift in Advanced Industrial Society, for example, Ronald Inglehart (1990, pp. 254-55) observed that, between 1979 and 1983, the Danish public was less favorable to the idea that "greater efforts should be made to reduce income inequality" than the Irish or the French public (71 percent in favor in Denmark, compared to 90 percent in Ireland and 93 percent in France). Similar results were obtained in recent studies. Stefan Svallfors (1993, p. 116), for instance, found that, contrary to what is expected, the Swedes appeared less "leftist" than the Germans and the British in their interpretation of inequality and in their attitudes towards redistribution. ${ }^{4}$ Many authors concluded that welfare state regimes do not structure public opinion as expected, and evoked explanations associated with "broad national political cultures" or "other influences such as "historical accident and the overall ideological climate"" (Papadakis \& Bean, 1993, p. 243; Döring, 1994, pp. 22-23 and 28-29). Inglehart (1990, pp. 254-55), however, argued these patterns made sense, because "the principle of diminishing marginal utility applies at the societal level, as well as the individual level." In Denmark, and in other Scandinavian countries, economic growth and social-democratic policies have been successful in achieving equality, to the point that further progress seems less necessary and is supported by fewer citizens (Inglehart, 1990, pp. 252-57).

Inglehart's interpretation, which associates these cross-national differences with a broad epochal shift toward post-materialism, has been criticized for being too mechanical. More satisfying than the image of a culture shift is the idea of a "conversation in context," whereby the public responds in a reasonable way to specific economic, social, and political circumstances 
(Sniderman, 1993; Clarke, Dutt, \& Rapkin, 1997; Clarke, Kornberg, McIntyre, Bauer-Kaase, \& Kaase, 1999). Over the years, note Max Kaase and Kenneth Newton (1995, p. 90), "support for economic equality has risen and fallen according to political events." Mass publics, explain these authors, do not simply support or oppose redistribution or the welfare state: "they discriminate between different parts of it, and between different policy instruments," and they do so “according to political influences which wax and wane in strength" (Kaase \& Newton, 1995, pp. 84 and 91). In this perspective, policy achievements are likely to be noticed by citizens. The American public, for instance, seems to respond and adjust to the government's spending decisions (Wlezien, 1995 and 1996). For an analysis of the politics of global justice, this implies, as Edeltraud Roller (1995, p. 195) notes, that "weak support for socio-economic equality policies cannot, a priori, be judged negatively. Weak support can be an expression of the fact that citizens no longer consider such policies necessary, due to the levels of income equality or wealth already attained." When a country has been relatively successful in the pursuit of equality at home, it is plausible that the public would not demand much more state intervention to reduce domestic income disparities but would, however, be very supportive of foreign aid. If this is the case, the egalitarian values of the public in social-democratic countries would resurface with respect to international justice, where so much remains to be done.

From these ideas about aggregate preferences and policy achievements, we can build a theoretical model that makes sense of public opinion and global justice. Our first proposition is that, at the aggregate level and in a cross-national perspective, we are likely to observe a negative relationship between support for redistribution at home and support for development assistance $\left(\mathrm{H}_{1}\right)$. This hypothesis is counter-intuitive in light of the foreign aid literature. It flows from the idea that mass publics are influenced by their country's political and social institutions, but also 
acknowledge the impact of policy results, at home and abroad. Previous studies have suggested that principles institutionalized through social policies shape what political actors "consider to be morally defensible behavior" (Rothstein, 1998, p. 138; see also Noël \& Thérien, 1995). This implies that the public should value equality more strongly and be more sensitive to international redistribution in countries with a social-democratic tradition. At the same time, if mass publics also take into account what has been achieved at home, support for domestic redistribution is likely to be lower in the very countries that prove more favorable to foreign aid.

A negative correlation between aggregate responses to questions about redistribution would be consistent with our model, but the best way to assess the relevance of policy achievements is to consider them explicitly. In this perspective, a country's level of income disparities is a good starting point. Our second hypothesis is that public support for domestic redistribution is higher where inequalities remain most important; thus, it should be positively associated with the magnitude of income disparities in a country $\left(\mathrm{H}_{2}\right)$.

Policy achievements can also be estimated by the type of welfare institutions in place in a given country. Conservative welfare state attributes, which characterize countries where state intervention is important but not egalitarian, should maintain public demand for redistribution at a high level $\left(\mathrm{H}_{3}\right)$, whereas socialist welfare state attributes, more conducive to equality, should reduce this demand $\left(\mathrm{H}_{4}\right){ }^{5}$ In the same manner, the cumulative power of the left, a good predictor of redistribution policies, should be negatively related to public support for a reduction of income disparities $\left(\mathrm{H}_{5}\right)^{6}$

With respect to development assistance, the relationships identified in $\mathrm{H}_{2}, \mathrm{H}_{3}, \mathrm{H}_{4}$, and H5 should be in the opposite direction. Public support for foreign aid should be negatively associated with a country's income disparities and with conservative welfare state attributes, and 
positively associated with socialist welfare state attributes and the cumulative power of the left. If the empirical evidence is consistent with this model, it would suggest that mass publics take into account the principles institutionalized in their country's welfare state, acknowledge policy achievements at home, and extend principles accepted domestically to the international arena.

\section{The Data}

Our model includes public opinion and policy variables. These variables can be captured by cross-sectional measures of public support for domestic and international redistribution, and by a series of indicators that have proved helpful in the study of the relationships between partisan politics, the welfare state, and foreign aid. For these indicators, we have a recent and complete set of data for ten European countries, namely Austria, Belgium, Denmark, Finland, France, Germany, Italy, the Netherlands, Sweden, and the United Kingdom. This sample is not ideal because it misses cases such as the United States and Japan, which are the two most important aid donors in absolute terms. There is, however, no better possibility. Eurobarometer surveys are the only sources of truly comparable data on these questions, and they constitute the standard tool for the comparative study of public opinion. For all its limitations, our ten-country sample remains satisfactory. It accounts for more than 50 percent of world foreign aid resources (OECD, 1999), and includes countries that present important variations with respect to the variables considered here.

For public opinion, our indicators are derived from 1995 answers to three Eurobarometer questions about redistribution (INRA, 1996). The first two questions are part of a broad list where respondents must identify problems as more or less important. In one case, they are asked 
whether they view "working towards reducing the number of very rich or very poor people" as an important problem $(\mathrm{Q} 1)$. The other question asks whether they consider that "helping the people in poor countries in Africa, South America, Asia, etc." is important or not (Q2). The third question stands alone and asks respondents to state whether they are for or against "helping the Third World countries" (Q3). We use the first question to measure public support for domestic redistribution, and the latter two for international redistribution. ${ }^{7}$ The Appendix presents the exact wording of the questions.

Four institutional and policy indicators are considered: conservative welfare state attributes, socialist welfare state attributes, left cumulative power, and the gini coefficient. Welfare state attributes are borrowed from Gøsta Esping-Endersen. Conservative attributes capture the degree of corporatism and etatism in a country's social programs, and socialist attributes reflect the extent of universalism in the same programs (Esping-Andersen, 1990, p. 77). Following other scholars, we assume the scores compiled by Esping-Andersen for 1980 remain fairly constant indicators of welfare state institutions over time (see, for instance, Janosky, 1994, p. 56; Stephens, 1996, pp. 32-65; Thérien \& Noël, 2000). The indicator for the cumulative power of the left was proposed by Huber, Ragin, and Stephens (1993) to measure the historical strength of leftist parties. A score of 1 , or a fraction when there is a coalition government, is given for each year, from 1946 onward, when the left is in power. Finally, the gini coefficient is a common indicator of a country's income distribution. In this case, the data are those of the Luxemburg Income Study. Complete definitions and sources are provided in the Appendix. Like the Eurobarometer responses, these policy indicators are fairly standard in the comparative politics literature. Two of them, socialist attributes and left cumulative power, have also been established as important determinants of foreign aid (Noël \& Thérien, 1995; Thérien \& Noël, 2000). 


\section{Results}

Table 1 presents the 1995 levels of public support for domestic and international redistribution in the ten countries of our sample. A number of preliminary observations can be made from this table. First, on average, support for domestic redistribution appears stronger than support for international redistribution. This is best viewed when one compares responses to the first two questions. Whereas 81.9 percent of Europeans consider that "working towards reducing the number of very rich or very poor people" is important (Q1), only 74.5 percent think the same about "helping the people in poor countries in Africa, South America, Asia, etc." (Q2). In 7 countries out of 10 , the first question elicits more positive answers than the second one. Second, our first measure of support for international redistribution (Q2) is somewhat lower than our second one $(\mathrm{Q} 3)$, but the two remain strongly correlated $(\mathrm{r}=0.92 * * *)$. Third, public support for domestic redistribution varies less among European countries than support for international redistribution. The standard deviation for the question on domestic redistribution is 1.5, compared to 6.0 and 6.5 for the questions on foreign aid. Foreign aid appears more controversial than domestic justice. Fourth, in many cases, differences between countries remain important. The preoccupation with domestic inequality varies from 67 percent in Denmark to 91 percent in France. Support for international redistribution goes from low scores of 59 percent and 65 percent for Belgium, the lowest country on questions 2 and 3, to high levels of 88 percent for Italy (in both questions) and 90 percent for the Netherlands (in Q3). 
TABLE 1. Levels of public support for domestic and international distribution, 1995

\begin{tabular}{|c|c|c|c|}
\hline & $\begin{array}{c}\text { Question } 1 \\
\text { Agree that Domestic } \\
\text { Redistribution is } \\
\text { Important }\end{array}$ & $\begin{array}{c}\text { Question } 2 \\
\text { Agree that } \\
\text { International } \\
\text { Redistribution is } \\
\text { Important }\end{array}$ & $\begin{array}{l}\text { Question } 3 \\
\text { Are in Favor of } \\
\text { International } \\
\text { Redistribution }\end{array}$ \\
\hline Austria & $83 \%$ & $62 \%$ & $69 \%$ \\
\hline Belgium & $86 \%$ & $59 \%$ & $65 \%$ \\
\hline Denmark & $67 \%$ & $81 \%$ & $89 \%$ \\
\hline Finland & $78 \%$ & $75 \%$ & $82 \%$ \\
\hline France & $91 \%$ & $67 \%$ & $73 \%$ \\
\hline Germany & $87 \%$ & $77 \%$ & $80 \%$ \\
\hline Italy & $86 \%$ & $88 \%$ & $88 \%$ \\
\hline Netherlands & $80 \%$ & $79 \%$ & $90 \%$ \\
\hline Sweden & $81 \%$ & $83 \%$ & $84 \%$ \\
\hline United Kingdom & $80 \%$ & $74 \%$ & $82 \%$ \\
\hline Mean & $81.9 \%$ & $74.5 \%$ & $80.2 \%$ \\
\hline Standard Deviation & 1.5 & 6.0 & 6.5 \\
\hline
\end{tabular}

Source: INRA, 1996. 
TABLE 2. Correlations between public support for redistribution and policy variables

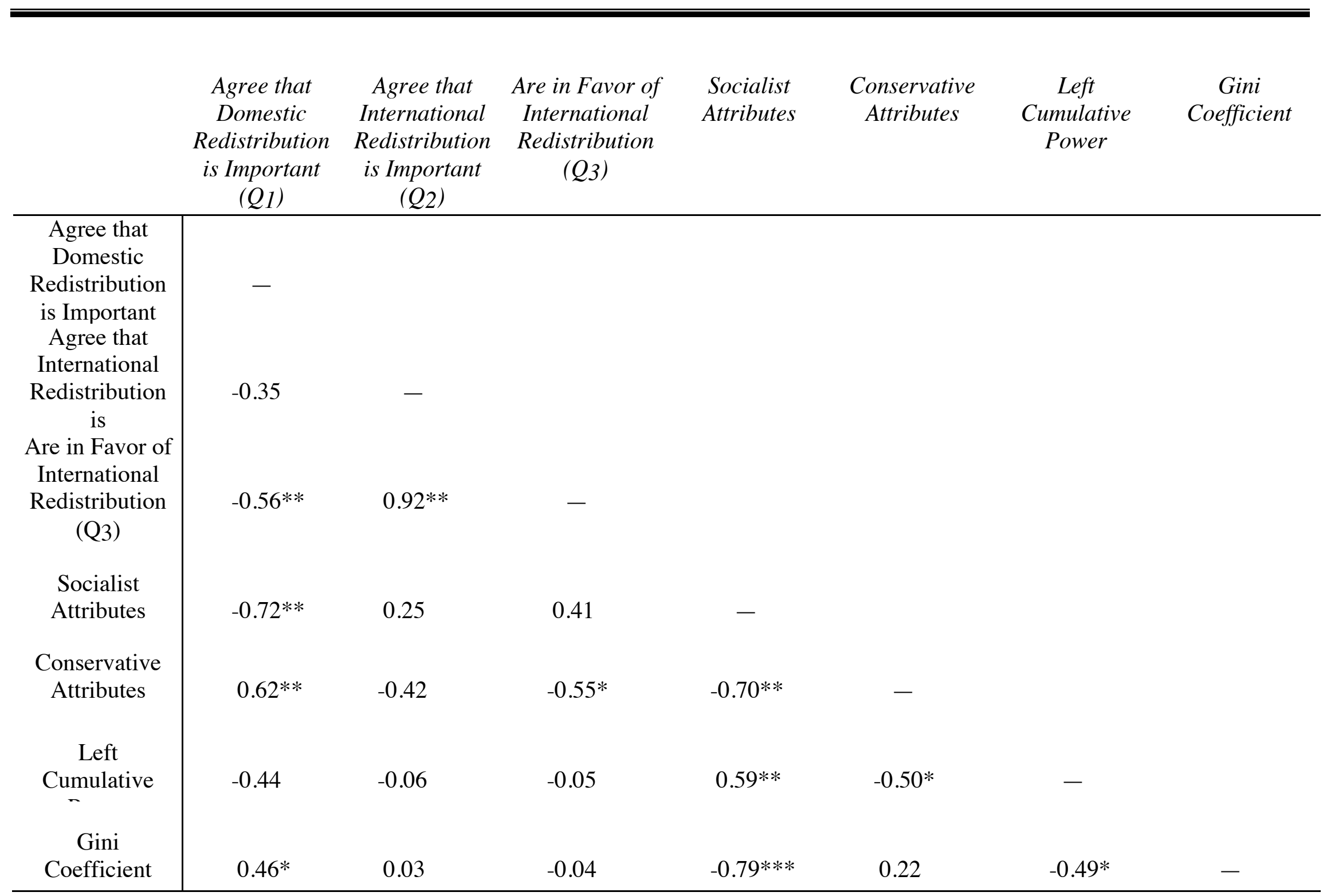

* Significant at 0.10 level; ** significant at 0.05 level; *** significant at 0.01 level (one-sided tests). 
Note: For the exact wording of the questions, the definitions of the variables and the sources, see the Appendix. 
Nationalists may see the slight priority and the more general support given to domestic inequality as unavoidable and sensible, particularly in a period of economic difficulties. The authors of the Eurobarometer report where these data are presented reason in this way and note that the rough economic conditions that prevailed in Europe in the early 1990s had an impact on public attitudes. European citizens, they argue, felt "more and more fragile in the face of the globalisation of the economy and its incapacity in dominating situations created by the economic recession: closing down of companies, unemployment, dualisation of society, marginalisation, spreading poverty, growing social exclusion" (INRA, 1996, Section B, p. 1). In these circumstances, the priority given by the European public to domestic over international redistribution may seem understandable. The difference in positive responses to the two issues, however, remains very small. Such a narrow gap hardly constitutes a confirmation that mass publics are more nationalist than cosmopolitan. The case of Denmark also stands out. This social-democratic country displays the lowest support for domestic redistribution and one of the highest scores in favor of helping Third World countries. Obviously, more is at stake than a simple projection of domestic priorities or than a straightforward trade-off between nationalist and cosmopolitan objectives.

Table 2 presents a correlation matrix that includes all the variables in our model. The main finding concerns the relationship between public support for domestic and for international redistribution. As expected in our model, the relationship is negative for both indicators of support for foreign aid. The association between concern for domestic inequality (Q1) and support for "helping the Third World countries" (Q3) is strong, negative, and significant ( $\mathrm{r}=$ $\left.0.56^{* *}\right){ }^{8}$ The relationship between the first and the second questions (Q1 and Q2) is not significant but it is also negative and fairly strong $(r=-0.35)$. 
Consider, first, public support for domestic redistribution. Table 2 indicates that approval for the idea of "reducing the number of very rich or very poor people" $\left(\mathrm{Q}_{1}\right)$ is negatively correlated with the cumulative power of the left $(r=-0.44)$ and socialist welfare state attributes $(r$ $\left.=-0.72^{* * *}\right)$, but positively correlated with conservative welfare state attributes $\left(\mathrm{r}=0.62^{* *}\right)$ and the gini coefficient $\left(\mathrm{r}=0.46^{*}\right)$. These results are in line with those obtained for earlier periods by authors like Inglehart, Svallfors, and Roller, and they are consistent with our theoretical model. In countries where the left has been powerful historically, and where a universalist welfare state has helped reduce income disparities, the demand for further income redistribution is lower. In contrast, in Austria, Belgium, France, Germany, and Italy, the left has been weaker, the welfare state more conservative and less egalitarian, and income disparities have remained more important. With good reasons, citizens of these countries tend to be preoccupied by domestic inequalities. ${ }^{9}$ Responses to survey questions about important problems may reflect values, but they also take into consideration a nation's institutions and policy record. The demand for domestic redistribution seems less pressing in more egalitarian countries.

With international redistribution, principles and values embodied in welfare state institutions seem to weigh more than other policy variables. Contrary to our hypotheses, left cumulative power and the gini coefficient are not associated with public support for foreign aid. ${ }^{10}$ Welfare state conservative attributes, however, are negatively and significantly correlated to the public approbation of help for Third World countries $\left(\mathrm{Q}_{3}\right)\left(\mathrm{r}=-0.55^{*}\right)$, and socialist attributes are positively correlated to the same response $(\mathrm{r}=0.41)$.

These weaker relationships may be explained by the presence of a few outliers in a small sample. Austria, for instance, has a socialist party that was often in power but contributed to build a conservative welfare state, with a weak commitment to social equality (Thérien \& Noël, 
2000). Italy is also a special case. Like the public of Ireland and of southern European countries such as Greece and Spain, Italians are strong supporters of foreign aid. This may be, as Eurobarometer reports suggest, because these countries have themselves benefited from European regional development programs (INRA, 1996, Section B, p. 71, and 1997, Annex 1, p. 50). It could also be a reflection of their specific situation, as "aspiring welfare states" (TaylorGooby, 1991, p. 134). Whatever the case, there is no clear relationship between support for foreign aid and the political balance of power of a country. The same is true for the level of income disparities. Welfare state attributes, on the other hand, are positively correlated with support for foreign aid. This is consistent with the idea that welfare state institutions contribute to shape what the public regards as "morally correct action" (Rothstein, 1998, p. 139). Compared to public support for domestic redistribution, attitudes on foreign aid seem less conditioned by partisan politics and the level of inequality, but almost as strongly influenced by welfare state institutions.

Contrary to conventional wisdom, public support for international redistribution is not simply a projection of support for domestic redistribution. It is precisely in countries where domestic redistribution appears less important that support for foreign aid is highest. In countries where the left is strong and where the welfare state embodies social-democratic principles, income disparities are less pronounced. The relationship between the cumulative power of the left and the gini coefficient is negative and significant $(\mathrm{r}=-0.49 *)$, and so is the relationship between socialist attributes and the gini coefficient $(\mathrm{r}=-0.79 * * *)$. In these cases, domestic income disparities appear less important to the public. This, however, only reflects policy achievements and does not mean the public has no regards for equality. Indeed, socialdemocratic institutions seem to facilitate public support for foreign aid. In more conservative 
welfare states, the situation is opposite. Conservative attributes are negatively correlated with the power of the left $(\mathrm{r}=-0.50 *)$ and positively associated with the gini coefficient $(\mathrm{r}=0.62 * *)$. This context, where inequalities at home have been neglected, is not favorable to strong public support for foreign aid.

Overall, our results are consistent with our theoretical model and with the general idea that public opinion on global justice is coherent. This coherence, however, cannot be seen through a simple relation between different survey responses. It appears when one interprets these responses in light of a country's institutions and policy record. When equality has been institutionalized as an important principle, the public acknowledges the results and support for foreign aid is high; when this is not the case and domestic disparities remain important, redistribution at home appears more pressing, and international justice less so. 


\section{Denmark and France: Distinct Visions of Global Justice}

The cases of Denmark and France present striking contrasts in public support for redistribution and can help illustrate our general argument. Denmark displays, by far, the lowest public support for domestic redistribution (67 percent), and France the highest (91 percent). Denmark also figures among the countries most supportive of foreign aid (81 and 89 percent on questions 2 and 3), whereas France is among the least favorable (67 and 73 percent).

Consider, first, the case of Denmark. With respect to social policy, this country stands among the most generous of the OECD, and it has a "combination of universal and insurancebased social security schemes financed largely from taxation" that situates it "firmly in the Scandinavian model" (Eardley, Bradshaw, Ditch, Gough, \& Whiteford, 1996, p. 112). Austerity measures were introduced in recent years, in particular by the bourgeois coalition in power between 1982 and 1993, but they did not undermine the core aspects of the welfare state and did not even make social policies less generous (Cox, 1997, p. 320). Many observers argue that, in fact, the Danish welfare state became more, not less, social-democratic during this period (GreenPedersen, 1999, pp. 248-49). As a result, Denmark's income distribution has remained relatively egalitarian (Green, Henley, \& Tsakalotos, 1994, p. 321). At the end of the 1980s, Denmark was the European Union member with the lowest proportion of poor persons (3.9 percent) and poor households (4.2 percent). ${ }^{11}$ Unemployment insurance and social assistance were so generous that they came "close to realizing a citizen-income model," and poverty remained a relatively marginal, most often transitory situation (Torfing, 1999, p. 19; see also Halleröd, Heikkilä, Mäntysaari, Ritakallio, \& Nyman, 1996, p. 331). In these conditions, poverty, inequality and domestic redistribution do not appear as pressing issues. A broad consensus exists around 
welfare institutions and policies and most social and political actors agree to maintain a relatively equal income distribution (Green-Pedersen, 1999, pp. 251-52; Torfing, 1999, pp. 21-22). Perceived as relatively marginal, poverty does not preoccupy the public as much as unemployment. Indeed, in the late 1980s and early 1990s, policy discussions did not focus on the gap between rich and poor, but rather on the possibility of maintaining a high employment level with the relatively small Danish wage dispersion (Nielsen \& Pedersen, 1989, p. 368; Eardley, Bradshaw, Ditch, Gough, \& Whiteford, 1996, p. 122; Torfing, 1999, p. 14). In these circumstances, the fact that Danes are less concerned than others by domestic income redistribution makes sense, and it appears fully compatible with both the country's welfare institutions and its citizens' generous views on foreign aid.

Danish aid policy - along with that of other Nordic states - has been characterized as "progressive" (Laatikainen, 1996, p. 109; see also Linder, 1998, p. 101). One of the first donor countries to reach the 0.7 percent of GNP international objective, Denmark was the most generous OECD country in 1998, with 0.99 percent of its GNP devoted to development assistance (Linder, 2000, p. 107). Important shares of Danish aid resources are also earmarked for the least developed countries and for multilateral agencies. According to Olav Stokke (1989b, p. 308, and 1989c, pp. 10-11), the country's aid policy "basically reflects humane internationalism," an approach that stresses equity and makes the alleviation of poverty a moral obligation for rich countries, as opposed to realist internationalism, where narrowly defined national interests prevail. This international orientation is supported by a broad political coalition. Only two far right parties in the Folketing reject the governmental objective of allocating 1 percent of the GNP to foreign aid (Randel \& German, 1998, p. 73). This convergence may be attributed, in part, to the important resources devoted by DANIDA, the 
Danish aid agency, to public education (Randel \& German, 1998, p. 74). It cannot be understood, however, in isolation from the strong consensus on the Danish welfare state. In the end, it seems fully appropriate to view Danish aid policy as "the projection of [the country's] social democracy" (Laatikainen, 1996, p. 110). More or less achieved at home, justice remains an important objective in the international arena.

With respect to domestic income redistribution, the French situation differs considerably from that of Denmark. Endowed with a complex system of social programs that protects unevenly various groups in the population, France has maintained relatively high levels of inequality and poverty (Atkinson, Rainwater, \& Smeeding, 1995, pp. 46-47; Eardley, Bradshaw, Ditch, Gough, \& Whiteford, 1996, p. 144; Hesse, 1999, pp. 15-29). If we leave aside poorer European Union members that provide little foreign aid, only Italy and the United Kingdom have a higher proportion of poor persons and poor households than France (where, in 1989, the proportions were 14.9 percent and 14.7 percent, respectively) (Paugam, 1996a, p. 391). In a relatively polarized political context, and with the Republican ideology of solidarity in the background, inequality and poverty have become important issues in France. In the 1980s, the notion of "social exclusion" came to occupy the "centre stage in French social policy reforms" (Silver \& Wilkinson, 1995, p. 285). Used by the right as well as by the left, this notion was a major theme of the 1995 presidential election, and it has informed subsequent reforms aimed at reducing poverty. Exclusion has become, writes a French social policy scholar, the "paradigm through which our society understands itself" (Paugam, 1996b, p. 7; see also Levy, 1999, pp. 251-52). Preoccupied by domestic inequalities, the French have constructed the problem as an important one, while they remained less sensitive to international development questions. 
Overall, French aid policy is more self-interested than Danish policy. France does have a "strong commitment" to development assistance (IFRI, 1997, p. 231). In recent years, for instance, it maintained the most generous aid/GNP ratio among G7 countries (OECD, 1999). French aid, however, has traditionally given priority to the promotion of the country's cultural and economic interests through the maintenance of a regional sphere of influence, referred to as the pré carré (Adda \& Smouts, 1989, p. 12; Sada, 1999, p. 223; see also Schraeder, Hook, \& Taylor, 1998, p. 301). According to Peter J. Schraeder (1996, p. 174), the motivations behind French development assistance policy have included the desire "to reassert France's historical position in the front rank of global powers." This objective explains why French development assistance has been concentrated on the country's former colonies and why the government has remained suspicious of multilateral agencies. The relatively weak support of French citizens for foreign aid has been accounted for by a lack of governmental efforts in development education, and by the complexity of a policy whose administrative structures appear particularly scattered (OECD, 1997, p. 18; Blamangin, 2000, p. 121). The realist character of this policy and the politics of a more conservative country preoccupied by domestic poverty probably provide better explanations of the French public's attitudes toward international justice.

In societies where universalist welfare state principles have been adopted and implemented, a commitment to international development seems easier to make, because it flows from already established principles of justice and because domestic distribution problems appear less pressing. In Denmark, for instance, the public is less concerned by domestic disparities and better able to extend abroad principles of justice accepted at home. In more conservative societies, the redistribution issue remains unsettled. The principles that could be used to argue for foreign aid remain weakly established at the domestic level and, as a consequence, the case 
for addressing domestic problems first appears more convincing. In France, domestic justice constitutes a major preoccupation, and the situation is less favorable to international redistribution. When they point in opposite directions, public attitudes about justice may seem at odds with the common sense. They are, in fact, perfectly coherent.

\section{Conclusion}

Public opinion on international redistribution is not a simple extension of public attitudes about domestic redistribution. On the contrary, when the two issues are associated, at the aggregate level, the relationship is significant but negative. This apparent inconsistency — which has been ignored by students of foreign aid - can be understood once we take into consideration the partisan situation, welfare state institutions, and the policy record of the different donor countries. In cases where the left has been powerful, has introduced universal social programs and has been effective in reducing income disparities, domestic inequalities appear less preoccupying, and foreign aid easier to advocate. In countries where the left has been weak, the welfare state conservative, and income distribution more uneven, poverty at home has remained a more significant issue, and foreign aid a more distant concern.

These findings help understand a situation that puzzles observers of American public opinion. In the United States, the public approves spending on foreign affairs and supports development assistance in principle, but nevertheless would prefer reducing the country's foreign aid. Some authors have attributed these seemingly contradictory attitudes to poor information about aid policy (Kull \& Ramsay, 2000, pp. 110-11), and others to skepticism about the effectiveness of development assistance in reducing poverty abroad (Page \& Barabas, 2000, pp. 
348-50). Our model suggests a different line of interpretation, more anchored in domestic politics. In a country with a weak left and large income disparities, ${ }^{12}$ the public predictably favors improved social programs and finds foreign aid more difficult to justify (Kull \& Ramsay, 2000, pp. 110-11; Page \& Barabas, 2000, p. 350).

Mass publics do not consider domestic and international justice as watertight compartments. They support international redistribution more strongly when principles of justice have been institutionalized domestically and when poverty has been tackled at home, and less strongly in the absence of such principles and achievements. If we understand global justice as a concept that reaches beyond the domestic/international divide to reason on moral issues across borders, we can conclude that public opinion is, in fact, considering justice in a global perspective.

Our findings contribute in various ways to a better understanding of public opinion, the welfare state, and development assistance. First, they lend comparative support to the idea, now dominant among students of public opinion, that mass publics may be ill informed but nevertheless prove coherent and reasonable. Public opinion on justice seems quite sophisticated, since it is based on relatively fair assessments of each country's institutional and policy achievements. As suggested by Sniderman and his co-authors (1996, pp. 244-49 and 257), mass publics appear to have a good understanding of the principles at stake and of the relevant policy context. This article clarifies, with the help of comparative and aggregate evidence, the way in which domestic and foreign policy attitudes are related. Contrary to what is often assumed, the public does not simply extend policy preferences to world problems. It articulates domestic and international preoccupations in a coherent way, more akin to a global reasoning than to a projection of national views. 
Second, our results help make sense of a difficulty long identified by students of public opinion about the welfare state. The fact that people in social-democratic countries prove less sensitive to domestic inequalities than others has often been presented as an intriguing puzzle, that casts a shadow on the conventional understanding of welfare state regimes. Inglehart and others have explained this result by the diminishing marginal utility of redistribution in wealthy, egalitarian countries. Because it did not consider foreign aid, however, this interpretation failed to recognize the complexity of debates about equality and, in particular, the lasting importance of public ideas about justice. The notion of policy achievements that has been proposed here appears more satisfying.

Third, the model presented in this article refines our understanding of public support for development assistance. This question has been discussed at length in policy circles, by specialists who suspect support for foreign aid may be broad but fragile, "a mile wide and an inch deep" (Smillie, 1998, p. 5). It has been an important theme in scholarly research as well, most authors agreeing to see public approval of foreign aid as an extension of support for domestic redistribution. Our findings suggest the logic at play is more complicated than this, and probably more solidly anchored in stable values and choices. If, indeed, it stems from institutionalized welfare state principles and from a fair assessment of domestic achievements, support for foreign aid is probably much deeper than "an inch." Beyond public opinion, the article also contributes to specify the relationship between the welfare state and foreign aid. This relationship, which has been established by many authors, now appears as truly political, because it is rooted in public perceptions of specific principles and policy achievements.

Empirical findings about the structure of public opinion cannot settle the philosophical debate over global justice that opposes nationalists and cosmopolitans. They suggest, however, 
that citizens do not see global justice as an either/or issue. Rightly or wrongly, they link domestic and international redistribution. It is true that the commitment to redistribute is stronger at the national level, but relationships of solidarity do not stop at national boundaries. The achievement of justice at home, in fact, sustains justice abroad. The idea that "charity begins at home" is not a "trap" that prevents us from treating foreign aid as a moral obligation (see Kapstein, 1999, p. 40). It is a fairly reasonable assessment of the real politics of global justice.

In interviews in poor neighborhoods of Boston, Dana Ansel (1996) collected numerous opinions like the following one, from a cafeteria line worker: "I have nothing against helping [some]body because I am all for helping people if I can, but I think before you can go way over there to another country and help those people, you need to help your own people first. And then, once you do that, you got the time or the money or whatever, then you help someone else." This statement connects the domestic and the international, and captures a good part of the logic we established in this article. In the end, it is not very different from the viewpoint of cosmopolitan philosopher Martha Nussbaum (1996, pp. 135-36), who concedes that starting at home is "the only sensible way to do good." The politics of justice cannot be only national or only international. It is, and must be, global. 
${ }^{1}$ For corroborating evidence, see Wittkopf, 1990, p. 215, and Holsti, 1996, p. 183.

${ }^{2}$ For qualitative comparisons arguing that national cultures explain redistribution policies at home and abroad, see Cooper \& van Themaat, 1989, p. 146, and Stokke, 1989b, p. 284.

${ }^{3}$ For similar conclusions, see Cooper \& van Themaat, 1989, p. 146.

${ }^{4}$ Similar findings are discussed in Papadakis \& Bean, 1993; Döring, 1994; Bean \& Papadakis, 1998; and Lapinski, Riemann, Shapiro, Stevens, \& Jacobs, 1998.

${ }^{5}$ On the relevance of conservative and socialist welfare state attributes, see EspingAndersen,1990; Huber, Ragin, \& Stephens, 1993; and Noël \& Thérien, 1995.

${ }^{6}$ On this variable, see Huber, Ragin, \& Stephens, 1993, and Thérien \& Noël, 2000.

${ }^{7}$ With the first two questions, support for redistribution includes the "very important" and "quite important" responses. For the third question, support corresponds to the sum of the "very much for" and of the "for - to some extent" numbers.

${ }^{8}$ To guarantee the robustness of this correlation, we computed it ten times, each time omitting a different case. The results proved stable.

${ }^{9}$ A similar interpretation is suggested, but not tested, in Taylor-Gooby, 1991, pp. 133-34.

${ }_{10}$ Stern (1998, p. 27), however, argues there is a "discernable relationship...between domestic income equality and support for aid."

${ }^{11}$ At the time, Denmark was the only Nordic country in the European Union (Paugam, 1996a, p. 391).

${ }^{12}$ In 1997, the United States had the highest gini coefficient among the OECD countries included in the Luxemburg Income Study data (http://www.lis.ceps.lu/ineqtable.htm). 
Note: For the exact wording of the questions, see the Appendix. 


\section{References}

Adda, Jacques, \& Smouts, Marie-Claude. (1989). La France face au Sud: le miroir brisé. Paris: Karthala.

Ansel, Dana. (1996, September). The Question is Welfare but the Answer is Foreign Aid: The Working Poor Speak. Paper presented at the Annual Meeting of the American Political Science Association, San Francisco.

Atkinson, Anthony B., Rainwater, Lee, and Smeeding, Timothy. (1995). Income Distribution in OECD Countries. Paris: OECD.

Bean, Clive, \& Papadakis, Elim. (1998). A Comparison of Mass Attitudes Towards the Welfare State in Different Institutional Regimes, 1985-1990. International Journal of Public Opinion Research, 10, 211-236.

Beitz, Charles R. (1999). International Liberalism and Distributive Justice: A Survey of Recent Thought. World Politics, 51, 269-296.

Blamangin, Olivier. (2000). France. In Judith Randel, Tony German \& Deborah Ewing (Eds.), The Reality of Aid 2000: An Independent Review of Poverty Reduction and Development Assistance (pp. 117-121). London: Earthscan Publications.

Clarke, Harold D., Dutt, Nitish, \& Rapkin, Jonathan. (1997). Conversations in Context: The (Mis)Measurement of Value Change in Advanced Industrial Societies. Political Behavior, 19, 19-39.

Clarke, Harold D., Kornberg, Allan, McIntyre, Chris, Bauer-Kaase, Petra, \& Kaase, Max. (1999). The Effect of Economic Priorities on the Measurement of Value Change: New Experimental Evidence. American Political Science Review, 93, 637-647.

Cooper, Charles, \& Verloren van Themaat, Joan. (1989). Dutch Aid Determinants, 1973-85: Continuity and Change. In Olav Stokke (Ed.), Western Middle Powers and Global Poverty: The Determinants of the Aid Policies of Canada, Denmark, the 
Netherlands, Norway, and Sweden (pp. 117-157). Uppsala: The Scandinavian Institute of African Studies.

Cox, Robert Henry. (1997). The Consequences of Welfare Retrenchment in Denmark. Politics \& Society, 25, 303-326.

Dalton, Russell J. (2000). Citizen Attitudes and Political Behavior. Comparative Political Studies, 33, 912-940.

DeMartino, George F. (2000). Global Economy, Global Justice: Theoretical Objectives and Policy Alternatives to Neoliberalism. London: Routledge.

Döring, Herbert. (1994). Public Perceptions of the Proper Role of the State. West European Politics, 17, 12-31.

Doyle, Michael W. (1997). Ways of War and Peace: Realism, Liberalism, and Socialism. New York: W. W. Norton.

Eardley, Tony, Bradshaw, Jonathan, Ditch, John, Gough, Ian, \& Whiteford, Peter. (1996). Social Assistance in OECD Countries. Volume II: Country Reports. Department of Social Security, Research Report 47. London: HMSO and Paris: OECD.

Esping-Andersen, Gøsta. (1990). The Three Worlds of Welfare Capitalism. Princeton: Princeton University Press.

Esping-Andersen, Gøsta. (1999). Social Foundations of Postindustrial Economies. Oxford: Oxford University Press.

Goodin, Robert E. (1988). What Is So Special About Our Fellow Countrymen? Ethics, 98, 663-686.

Green, Francis, Henley, Andrew, \& Tsakalotos, Euclid. (1994). Income Inequality in Corporatist and Liberal Economies: A Comparison of Trends within OECD Countries. International Review of Applied Economics, 8, 303-331. 
Green-Pedersen, Christoffer. (1999). The Danish Welfare State under Bourgeois Reign: The Dilemma of Popular Entrenchment and Economic Constraints. Scandinavian Political Studies, 22, 243-260.

Halleröd, Björn, Heikkilä, Matti, Mäntysaari, Mikko, Ritakallio, Veli-Matti, \& Nyman, Charlott. (1996). The Nordic Countries: Poverty in a Welfare State. In Else Øyen, S. M. Miller \& Syed Abdus Samad (Eds.), Poverty: A Global Review; Handbook on International Poverty Research (pp. 325-353). Oslo: Scandinavian University Press.

Hesse, Philippe-Jean. (1999). Le 'modèle' français: comme un essaim de chauves-souris. In Denis Bouget \& Bruno Palier (Eds.), Comparer les systèmes de protection sociale en Europe du Nord et en France, Volume 4: Rencontres de Copenhague (pp. 15-29). Paris: Ministère de l'Emploi et de la solidarité.

Hill, Kevin A. (1993). The Domestic Sources of Foreign Policymaking: Congressional Voting and American Mass Attitudes Toward South Africa. International Studies Quarterly, 37, 195-214.

Holsti, Ole R. (1992). Public Opinion and Foreign Policy: Challenges to the AlmondLippmann Consensus. International Studies Quarterly, 36, 439-466.

Holsti, Ole R. (1996). Public Opinion and American Foreign Policy. Ann Arbor: University of Michigan Press.

Huber, Evelyne, Ragin, Charles, \& Stephens, John D. (1993). Social Democracy, Christian Democracy, Constitutional Structure, and the Welfare State. American Journal of Sociology, 99, 711-749.

Hurrell, Andrew, \& Woods, Ngaire. (1999). Introduction. In Andrew Hurrell and Ngaire Woods (Eds.), Inequality, Globalization, and World Politics (pp. 1-7). Oxford: Oxford University Press. 
Inglehart, Ronald. (1990). Culture Shift in Advanced Industrial Society. Princeton: Princeton University Press.

IFRI (Institut français des relations internationales). (1997). La fin de l'aide au développement? In IFRI (Ed.), Rapport annuel mondial sur le système économique et les stratégies 1998 (pp. 221-244). Paris: Dunod.

INRA (International research associates). (1996). Eurobarometer 44.1. The Way Europeans Perceive Developing Countries in 1995. Report prepared for the European Commission. Brussels: INRA.

INRA (International research associates). (1997). Eurobarometer 46.0. Development Aid: Building for the Future with Public Support. Report prepared for the European Commission. Brussels: INRA.

Janosky, Thomas. (1994). Direct State Intervention in the Labor Market: The Explanation of Active Labor Market Policy from 1950 to 1988 in Social Democratic, Conservative, and Liberal Regimes. In Thomas Janosky \& Alexander M. Hicks (Eds.), The Comparative Political Economy of the Welfare State (pp. 54-92). Cambridge: Cambridge University Press.

Jones, Charles. (1999). Global Justice: Defending Cosmopolitanism. Oxford: Oxford University Press.

Kaase, Max, \& Newton, Kenneth. (1995). Beliefs in Government. Volume 5: Beliefs in Government. Oxford: Oxford University Press.

Kapstein, Ethan B. (1999). Reviving Aid, Or Does Charity Begin at Home? World Policy Journal, 16, 35-44.

Kull, Steven \& Ramsay, Clay. (2000). Challenging U.S. Policymakers' Image of an Isolationist Public. International Studies Perspectives, 1, 105-117. 
Laatikainen, Katie Verlin. (1996). The Disillusionment of Nordic Aid. In Steven W. Hook (Ed.), Foreign Aid Toward the Millennium (pp. 109-124). Boulder: Lynne Rienner.

Lapinski, John S., Riemann, Charles R., Shapiro, Robert Y., Stevens, Matthew F. \& Jacobs, Lawrence R. (1998). Welfare State Regimes and Subjective Well-Being: A CrossNational Study. International Journal of Public Opinion Research, 10, 2-24.

Levy, Jonah D. (1999). Vice into Virtue? Progressive Politics and Welfare Reform in Continental Europe. Politics \& Society, 27, 239-273.

Linder, Bibi. (1998). Denmark. In Judith Randel \& Tony German (Eds.), The Reality of Aid 1998/1999: An Independent Review of Poverty Reduction and Development Assistance (pp. 101-106). London: Earthscan Publications.

Linder, Bibi. (2000). Denmark. In Judith Randel, Tony German \& Deborah Ewing (Eds.), The Reality of Aid 2000: An Independent Review of Poverty Reduction and Development Assistance (pp. 104-109). London: Earthscan Publications.

Lumsdaine, David H. (1993). Moral Vision in International Politics: The Foreign Aid Regime 1949-1989. Princeton: Princeton University Press.

Mason, Andrew. (1997). Special Obligations to Compatriots. Ethics, 107, 427-447.

Miller, David. (1999). Justice and Global Inequality. In Andrew Hurrell \& Ngaire Woods (Eds.), Inequality, Globalization, and World Politics (187-210). Oxford: Oxford University Press.

Nielsen, Klaus, \& Pedersen, Ove K. (1989). Is Small Still Flexible? - An Evaluation of Recent Trends in Danish Politics. Scandinavian Political Studies, 12, 343-371.

Noël, Alain, \& Thérien, Jean-Philippe. (1995). From Domestic to International Justice: The Welfare State and Foreign Aid. International Organization, 49, 523-553. 
Nussbaum, Martha C. (1996). Reply. In Martha C. Nussbaum \& Joshua Cohen (Eds.), For Love of Country: Debating the Limits of Patriotism (pp. 131-144). Boston: Beacon Press.

OECD (Organisation for economic co-operation and development). (1997). France. Development Co-operation Review Series, no. 21. Paris: OECD.

OECD (Organisation for economic co-operation and development). (1999). Development Cooperation 1998. Paris: OECD.

Page, Benjamin I., \& Barabas, Jason. (2000). Foreign Policy Gaps between Citizens and Leaders. International Studies Quarterly, 44, 339-364.

Page, Benjamin I., \& Shapiro, Robert Y. (1992). The Rational Public: Fifty Years of Trends in Americans' Policy Preferences. Chicago: University of Chicago Press.

Papadakis, Elim, \& Bean, Clive. (1993). Popular Support for the Welfare State: A Comparison Between Institutional Regimes. Journal of Public Policy, 13, 227-254.

Paugam, Serge. (1996a). Pauvreté et exclusion: la force des contrastes nationaux. In Serge Paugam (Ed.), L'exclusion: l'état des savoirs (pp. 389-404). Paris: La découverte.

Paugam, Serge. (1996b). Introduction: la constitution d'un paradigme. In Serge Paugam (Ed.), L'exclusion: l'état des savoirs (pp. 7-19). Paris: La découverte.

Pratt, Cranford, (Ed.). (1989). Internationalism Under Strain: The North-South Policies of Canada, the Netherlands, Norway, and Sweden. Toronto: University of Toronto Press.

Randel Judith, \& German, Tony. (1998). Denmark. In Tony German, Henny Helmich, Judith Randel \& Ian Smillie (Eds.), Public Attitudes and International Development Cooperation (pp. 61-65). Paris: OECD. 
Roller, Edeltraud. (1995). The Welfare State: The Equality Dimension. In Ole Borre \& Elinor Scarbrough (Eds.), Beliefs in Government. Volume 3: The Scope of Government (pp.165-197). Oxford: Oxford University Press.

Rothstein, Bo. (1998). Just Institutions Matter: The Moral and Political Logic of the Universal Welfare State. Cambridge: Cambridge University Press.

Russett, Bruce. (1993). Grasping the Democratic Peace: Principles for a Post-Cold War World. Princeton: Princeton University Press.

Sada, Hugo. (1999). Le changement à petits pas des relations franco-africaines. Revue internationale et stratégique, 33, 222-232.

Satz, Debra. (1999). Equality of What Among Whom? Thoughts on Cosmopolitanism, Statism, and Nationalism. In Ian Shapiro \& Lea Brilmayer (Eds.), Global Justice (pp. 67-85). New York: New York University Press.

Schraeder, Peter J. (1996). Foreign-Aid Posturing in Francophone Africa. In Steven W. Hook (Ed.), Foreign Aid Toward the Millennium (pp. 173-189). Boulder: Lynne Rienner.

Schraeder, Peter J., Hook, Steven W., \& Taylor, Bruce. (1998). Clarifying the Foreign Aid Puzzle: A Comparison of American, Japanese, French, and Swedish Aid Flows. World Politics, 50, 294-323.

Shapiro, Ian, \& Brilmayer, Lea. (1999). Introduction. In Ian Shapiro \& Lea Brilmayer (Eds.), Global Justice (pp. 1-11). New York: New York University Press.

Silver, Hilary, \& Wilkinson, Frank. (1995). Policies to Combat Social Exclusion: A FrenchBritish Comparison. In Gerry Rodgers, Charles Gore \& José B. Figueiredo (Eds.), Social Exclusion: Rhetoric, Reality, Responses (pp. 283-310). Geneva: International Labour Organisation. 
Smillie, Ian. (1996). Mixed Messages: Public Opinion and Development Assistance in the 1990s. In Colm Foy \& Henny Helmich (Eds.), Public Support for International Development (pp. 27-54). Paris: OECD.

Smillie, Ian. (1998). Optical and Other Illusions: Trends and Issues in Public Thinking About Development Co-operation. Paper presented at the Conference on "Stakeholders for Development: Government-NGO Dialogue on the $21^{\text {st }}$ Century Partnership Strategy." Paris: OECD.

Sniderman, Paul M. (1993). The New Look in Public Opinion Research. In Ada W. Finifter (Ed.), Political Science: The State of the Discipline II (pp. 219-245). Washington, D.C.: American Political Science Association.

Sniderman, Paul M., Fletcher, Joseph F., Russell, Peter H., \& Tetlock, Philip E. (1996). The Clash of Rights: Liberty, Equality, and Legitimacy in Pluralist Democracy. New Haven: Yale University Press.

Stephens, John D. (1996). The Scandinavian Welfare States: Achievements, Crisis, and Prospects. In Gøsta Esping-Andersen (Ed.), Welfare States in Transition: National Adaptations in Global Economies (pp. 32-65). London: Sage and United Nations Research Institute for Social Development.

Stern, Marc. (1998). Development Aid: What the Public Thinks, ODS Working Paper 4. New York: Office of Development Studies, United Nations Development Program.

Stokke, Olav (Ed.). (1989a). Western Middle Powers and Global Poverty: The Determinants of the Aid Policies of Canada, Denmark, the Netherlands, Norway, and Sweden. Uppsala: The Scandinavian Institute of African Studies.

Stokke, Olav. (1989b). “The Determinants of Aid Policies: Some Propositions Emerging from a Comparative Analysis.” In Olav Stokke (Ed.), Western Middle Powers and Global Poverty: The Determinants of the Aid Policies of Canada, Denmark, the 
Netherlands, Norway, and Sweden (pp. 275-322). Uppsala: The Scandinavian Institute of African Studies.

Stokke, Olav. (1989c). The Determinants of Aid Policies: General Introduction. In Olav Stokke (Ed.), Western Middle Powers and Global Poverty: The Determinants of the Aid Policies of Canada, Denmark, the Netherlands, Norway, and Sweden (pp. 9-31). Uppsala: The Scandinavian Institute of African Studies.

Svallfors, Stefan. (1993). Policy Regimes and Attitudes to Inequality: A Comparison of Three European Nations. In Thomas P. Boje \& Sven E. Olsson Hort (Eds.), Scandinavia in a New Europe (pp. 87-133). Oslo: Scandinavian University Press.

Taylor-Gooby, Peter. (1991). Social Change, Social Welfare and Social Science. Toronto: University of Toronto Press.

Thérien, Jean-Philippe. (1999). Beyond the North-South Divide: The Two Tales of World Poverty. Third World Quarterly, 20, 723-742.

Thérien, Jean-Philippe, \& Lloyd, Carolyn. (2000). Development Assistance on the Brink. Third World Quarterly, 21, 21-38.

Thérien, Jean-Philippe, \& Noël, Alain. (2000). Political Parties and Foreign Aid. American Political Science Review, 94, 151-162.

Torfing, Jacob. (1999). Workfare with Welfare: Recent Reforms of the Danish Welfare State. Journal of European Social Policy, 9, 5-28.

Walzer, Michael. (1983). Spheres of Justice: A Defense of Pluralism and Equality. New York: Basic.

Wittkopf, Eugene R. (1990). Faces of Internationalism: Public Opinion and American Foreign Policy. Durham: Duke University Press.

Wlezien, Christopher. (1995). The Public as Thermostat: Dynamics of Preferences for Spending. American Journal of Political Science, 39, 981-1000. 
Wlezien, Christopher. (1996). Dynamics of Representation: The Case of US Spending on Defence. British Journal of Political Science, 26, 81-103.

Wood, Bernard. (1996). Account of the Experts' Consultation. In Colm Foy \& Henny Helmich (Eds.), Public Support for International Development (pp. 19-25). Paris: OECD. 